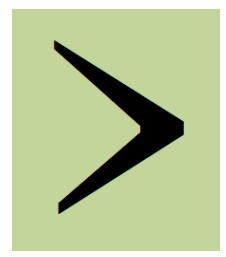

\author{
Papers in Historical Phonology \\ http://journals.ed.ac.uk/pihph \\ ISSN 2399-6714 \\ Volume 1, 90-108 \\ DOI : $10.2218 /$ pihph.1.2016.1695
}

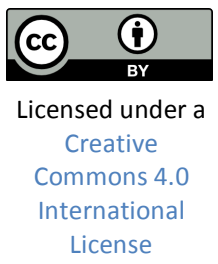

\title{
Towards a definition of an Egyptian Greek variety
}

\author{
SONJA DAHLGREN \\ University of Helsinki
}

\begin{abstract}
In this paper I study the possibility of an Egyptian Greek variety that on the phonological level - developed from the $2^{\text {nd }}$ century CE onward, and which has so far not been defined as an independent language variety. Some preliminary remarks on this have been made, based on the great amount of features present in Greek in Egypt potentially stemming from the contact with Egyptian. Greek texts from Egypt display a substantial amount of nonstandard variation on all linguistic levels. In this paper I investigate the phonological level, concentrating on vowel orthography. Preliminary results of my study indicate Coptic phonological influence in, for example, the allophonic distribution of unstressed vowels, the tendency for consonant-to-vowel coarticulatory effects, and transfer of the Egyptian stress system. Parallel material can be found in the nonstandard usage of Greek loanwords in Coptic, which are used as a comparison for the Greek nonstandard writing forms. In order to be able to differentiate between Coptic impact and Greek internal phonological variation in the analysis of the phonetic variants, Coptic phoneme qualities are compared to the nonstandard renderings of Arabic loanwords in Coptic which display the same phenomena as the Greek ones.
\end{abstract}

\section{Introduction and previous studies}

After the conquest of Egypt by Alexander the Great in 332 BCE, Greek was introduced to the Egyptian administration and soon became the official language of the Egyptian government, being in use until ca. the $8^{\text {th }}$ century. It seems that over time, a new variety of Greek developed from the imperfect learning of the Egyptian L2 Greek users, and on phonological level the development of this variety can be seen in texts from the $2^{\text {nd }}$ to the $8^{\text {th }}$ century $C E$, in various nonstandard orthographic forms. After an initial period where writing was performed only by Greek officials, Egyptian scribes were educated in Greek in order to carry out administrative work. These second language users of Greek were also largely responsible for much of private Greek-language correspondence for Egyptians who could not write (Clarysse 1993, 186- 
188; 200-201). Hence, for the most part, documents were produced by second language users with varying levels of Greek competence; some could write perfect Greek, and others less so. This is evident in an array of misspellings and, for example, confusion in the use of the Greek case system. Since Egyptian did not have case inflection, this particular aspect of Greek was alien to the Egyptian writers, who often either used the nominative for all purposes or relied on guesswork in choosing the case (Leiwo 2003, 5-7). Similarly, while much of the writing was according to the Greek standard, when there was nonstandard orthographic variation in the writing of the Egyptians, it often revealed features of their L1 phonological system.

This situation creates fruitful ground for studying nonstandard variation and reveals transfer from Egyptian to Greek on all linguistic levels. The occurrence of (morpho)syntactic transfer has been verified for example in relative clause constructions (Vierros 2012, 177-194). Misspellings present in nonstandard orthography have their basis in phonology, and paint a clear picture of some of the well-known Greek developments, such as monophthongisation, the loss of vowel quantity, and the raising and fronting of close-mid unrounded [e] and close rounded vowels, $[\mathrm{y}, \varnothing]$ to [i]. One of the key issues is that there are few Greek texts available outside of Egypt from the post-Classical period text production had been transferred to papyrus and other perishable materials, and only Egypt has soil dry enough to preserve texts in large quantities. Therefore, it cannot be taken as a given that all the phonological variation is of Greek internal origin. In fact, taking into account that a language contact situation existed, it is highly probable that a substantial amount of the phonologically/phonetically-based nonstandard variation derives from the phonological system of Egyptian. ${ }^{1}$ This matter has been investigated to some extent in Gignac (1976) and Gignac (1981). Although these grammars are thorough, they are only primarily catalogues of all the phenomena found in the Greek used in Egypt, with some occasional and quite cautious remarks on the possible effects of bilingualism. Gignac (1991) finally gives a more definite view on the impact of Egyptian on Greek, and Greek loanwords

\footnotetext{
1 The term 'Egyptian' refers to the language in general and structures that were probably in place before the Coptic stage, while 'Coptic' is used in reference to evidence that can only be obtained from Coptic, the variety of Egyptian which was in use from ca. $2^{\text {nd }}-3^{\text {rd }}$ century onwards and which employed the Greek alphabet for writing. Coptic was the first Egyptian writing system to have vowel graphemes, and therefore, for instance, vowel qualities can only be discussed within the framework of Coptic phonology, while the stress system of the language is a structure which can be assumed to predate Coptic. The earliest texts from Coptic come from the 2nd century $\mathrm{CE}$, and Coptic is the first stage of Egyptian to openly show borrowings from Greek.
} 
in Coptic are mentioned as good parallel material for some of the vowel changes. In the field of Coptology, Girgis (1966) already lists some of the more frequent nonstandard phonetic variants which occur in the vowel spellings of Greek loanwords in Coptic. Using these earlier studies as a basis for my work, I have investigated the impact of Egyptian on Greek vowel orthography (Dahlgren 2016; in preparation (doctoral dissertation)). During the course of this work, I have come to the conclusion that, on the phonological level, there are markers of an emerging independent language variety of L2 Greek usage in Egypt.

In this paper, I propose some criteria for defining an Egyptian Greek variety on the level of phonology, concentrating on vowel quality. The subject has received very little attention in the field of Classics, and for the most part the deviant features in the Greek texts of Egypt have been attributed to imperfect learning (e.g. Bagnall 2007). However, Horrocks $(2010,111-114,168-172)^{2}$ has given a preliminary account of the transfer of Egyptian phonological structures to Greek including e.g. the interchangeable use of voiced and voiceless stops and the confusion of unstressed /a, e, o/, from which I have expanded the phonetic analysis in Dahlgren (in prep.); for instance, no attention to the possible impact of the Egyptian stress system on Greek has been given so far, and the nonstandard variation of /i, e/ has not been seen as anything else than a Greek internal phenomenon. Some of my major findings include underdifferentiation of Greek phonemes, Egyptian-influenced allophonic variation, and even transfer of Egyptian stress; all of these are among the phonological phenomena that are paralleled in the treatment of Greek loanwords in Coptic.

For the present study, I examined Egyptian transfer effects in the Greek of Egypt through the Narmouthis Greek collection (O.Narm., 133 texts), which is particularly rich with regard to Egyptian transfer. The texts belong to the documentary genre, which contains more nonstandard variation than literary texts as a general principle, and mostly consist of tax receipts and other administrative material; even potential school (writing) exercises in the form of name lists (Pintaudi \& Siejpesteijn 1993, 13). The Greek texts seem to have mostly been written in a school environment, (possibly by scribe apprentices) with limited Greek knowledge (Bagnall 2007, 13-17). Imperfect learning, then, as Bagnall suggests, seems to form a part of the reason behind the

\footnotetext{
2 One major contribution for the phonology of Greek in Egypt before Horrocks (1997) was Teodorsson (1977) but as Horrocks 2010 (2 ${ }^{\text {nd }}$ (revised) edition) summarises the work and relevant findings of Teodorsson with significant updating of his results, I have used it as the main reference for Greek phoneme inventory for the time period analysed in this paper.
} 
spelling variation. Greek internal phonological development affected the phoneme-grapheme correspondences similarly to what can be seen in e.g. modern English, and the writers of the texts did not always remember the standard form of Greek words, probably due to their unfinished education. In these instances, estimations based on the phonetic form of the words were used but the near-phonetic spellings were often such as cannot be explained with the Greek phonological developments; for instance the confusion between /o/ and /u/, which are both still distinctive phonemes in Modern Greek. Presumably, then, these types of misspellings could be based on Egyptian vowel qualities.

After a phonological analysis of the Narmouthis ostraca, I explored how the findings relate to the use of Greek in Egypt in general, using the resources provided by The Papyrological Navigator, ${ }^{3}$ an open-access Internet platform currently holding ca. 70,000 Greek texts. I also sought parallel evidence from the treatment of Greek loanwords in Coptic. I gathered ca. 450 nonstandard variants of Greek loanwords in Coptic from the database of DDGLC (Database and Dictionary of Greek Loanwords in Coptic, FU Berlin), displaying the phonological phenomena described above. Coptic is the Egyptian language form relevant for this study for two reasons. First, it dates to ca. $2^{\text {nd }}$ century CE (i.e. the same period as O.Narm.: $1^{\text {st }}-3^{\text {rd }}$ c. CE). Second, it is the first form of Egyptian to employ vowel graphemes in writing. Comparisons between the phonological systems of Greek and Egyptian could not have been made in any sensible manner with the pre-Coptic stages of Egyptian, for obvious reasons. I present here the preliminary results further explored in Dahlgren (in prep.).

\section{Some features of Greek in Egypt}

Horrocks has made some observations on a number of phonological features that seem to indicate an independent variety of Greek spoken in Egypt. Among these are, for example, stress-related confusion of /a, e, o/ word-finally, underdifferentiation of voiced/voiceless stops, and the phoneme /o/ being realised as / $\mathrm{u} /(2010,112)$. Many of these features seem to result from Egyptian influence. For instance, Coptic did not have a contrast between voiced and voiceless stops. Instead, there was a phonological opposition between voiceless stops and ejectives (Loprieno 1995, 40-44). A similar case can be made for the realisation

3 All searches have been performed in DDbDP (Duke Database of Documentary Papyri) in the Papyrological Navigator. Consequently, the text corpora are referred to by the abbreviations used in DDbDP. 
of /o/ as /u/: Coptic had no unstressed /o/, so Greek /o/ in this position was often replaced with another sound from the inventory of unstressed vowels. Word-finally this was often /e/ or /a/, in a medial position more frequently /u/ (Peust 1999, 250-254). Underdifferentiation also explains the realisation of Greek /y/ as /u/ (Dahlgren 2016 and in more detail Dahlgren in prep.). The vowel inventories of Greek (following Horrocks 2010, 167-168) and Egyptian (following Peust 1999, 201) ${ }^{4}$ during the period of the Narmouthis ostraca are compared below in (1).

(1) Vowel inventories of Greek and Coptic in $2^{\text {nd }}$ century CE ${ }^{5}$

$\begin{array}{ll}\text { Greek } & \\ \text { /i/ } & <\mathrm{i}, \text { ei }> \\ \text { /y/ } & <\mathrm{y}, \text { oi }> \\ \text { /e/ } & <\overline{\mathrm{e}}> \\ / \varnothing / & <\mathrm{y}, \text { oi }> \\ \text { /e/ } & <\mathrm{e}, \mathrm{ai}> \\ \text { /a/ } & <\mathrm{a}> \\ \text { /o/ } & <\mathrm{o}, \overline{\mathrm{o}}> \\ \text { /u/ } & <\mathrm{ou}>\end{array}$

Coptic

/i/ $\quad<(e)$ i $>$

$/ \mathrm{e} /<\overline{\mathrm{e}}>$

$\mid \varepsilon / \quad<\mathrm{e}>$

$/ \mathrm{a} / \quad<\mathrm{a}>$

$/ \mathrm{s} /<0>$

$/ \mathrm{o} /<\overline{\mathrm{o}}>$

$/ \mathrm{u} / \quad<\mathrm{ou}>$

In the examples below, I present instances of the phonological phenomena first in the texts of O.Narm., and then in another (random) sample corpus from across Egypt. Examples (2) and (3) show underdifferentiation of Greek phonemes in Greek texts from Egypt.

4 There is disagreement among Coptologists on whether the vowel qualities represented by the Greek long and short vowel graphemes differed in quantity or quality in Coptic phonology. In this paper the quality hypothesis is followed (see discussion of the matter in Peust 1999, 201-210).

5 Greek script is here transliterated into a phonetic approximate in Roman script, given in angled brackets. The proposed phonemic values are also given in slanted brackets. Elsewhere, approximate phonetic values are given in italics. Vowel quantity had been lost in Greek by this time; as a result, the former $\omega<\overline{0}>$ and $0<0>$ had merged and were both phonetically [o] in the $2^{\text {nd }}$ century CE, leading to additional confusion we do not tackle here mainly because it is not related to different phoneme qualities. Therefore, the original quantity difference is not conveyed here in the transcription. The difference between the graphemic counterparts of the front vowels $\eta<\overline{\mathrm{e}}>$ and $\varepsilon<\mathrm{e}>$, however, is important since, in the $2^{\text {nd }}$ century, $\eta<\overline{\mathrm{e}}>$ was developing from its earlier phonemic quality, /ę/, into [i], while $\varepsilon<\mathrm{e}>$ remained [e]. In this paper $\eta<\overline{\mathrm{e}}>$ is still transcribed as $<\overline{\mathrm{e}}>$ because the process was still unfinished, and during the first centuries CE it still varied substantially with $\varepsilon<\mathrm{e}>$. Greek /u/ was, as it is still today, represented by the digraph ov $<0 u>$ and transcribed as the single grapheme $u$. 
(2) Underdifferentiation of / $d, t /$

$\begin{array}{lll}\begin{array}{l}\text { Standard } \\ \text { <adelfō> adelfó }\end{array} & \begin{array}{l}\text { Nonstandard } \\ \text { <atelfō> atelfo }\end{array} \\ \text { <eisodos> eísodos } & \text { <eisotos> eisotos } 103.5 & \text { P.Ryl. } 2.160 .4\end{array}$

(3) Underdifferentiation of / $y$, u/

$\begin{array}{lllll}\begin{array}{l}\text { Standard } \\ \text { <pyrou> }\end{array} & \text { pyrú } & \begin{array}{l}\text { Nonstandard } \\ \text { <pourou> }\end{array} & \text { puru } & \text { O.Narm. } 42.6 \\ \text { <anesyren> } & \text { anésyren } & \text { <anesouren> } & \text { anesuren } & \text { P.Oxy. 6.2758.12 }\end{array}$

In (2), the original Greek /d/ in adelfó 'brother (dat.)' has been replaced with / $t$ /, showing just one of the many ${ }^{6}$ instances of how the Egyptian writers handled the Greek voiced/voiceless distinction. In (3), the same fate has fallen upon Greek /y/: in O.Narm. 42.6 the standard pyrú 'wheat (gen.)' has been written nonstandardly with <ou> /u/ in both syllables, and in P.Oxy. 36.2758.12, the standard /y/ in anésyren has similarly been replaced with $/ \mathrm{u} /$, creating the nonstandard $<$ anesouren $>$ anesuren 'to pull up one's clothes'.

One aspect of the nonstandard language use often seen in Greek texts coming from Egypt is especially multicausal and opaque, namely the eventual merging of the Greek near-close front unrounded $(<\overline{\mathrm{e}}>$ $/ \mathrm{e} /$ ), close-mid front rounded $(<\mathrm{oi}>/ \varnothing /)$ and close front rounded $(<\mathrm{y}>$ $/ y /$ ) vowels into a single unrounded close front vowel, resulting in several graphemes being pronounced as [i]. This is a language-internal development for which an abundance of evidence is found already from the Classical period and from everywhere in the Greek-speaking world. Spelling variants based on this, however, were more regular in Egypt than elsewhere, as Coptic had only three front vowels $(/ \mathrm{i}, \mathrm{e}, \varepsilon /)$ to

\footnotetext{
6 The Trismegistos Text Irregularities Database - a phoneme-based search engine linked to the nonstandard attestations in the Papyrological Navigator (PN) - gives 938 instances of $<\mathrm{d}>$ being replaced by $<\mathrm{t}>$ and 492 of $<\mathrm{t}>$ being replaced by $<\mathrm{d}>$, to give an example of the amount of similar nonstandard forms. $<$ ou $>/ u /$ for $<y>/ y /$ is rarer, with 121 attestations, while there are 188 instances of $<y>/ y /$ for $<$ ou $>/ u /$. This is the amount of nonstandard /d, t/ and /y, u/ etc. usages out of ca. 70,000 Greek texts, which gives some indication of the overall quantity of nonstandard spellings. Obtaining statistical information on the whole standard-nonstandard ratio is difficult and time-consuming even on smaller samples because only nonstandard forms are marked in the search engines, word forms in the PN and spelling graphemes in Trismegistos, so standard forms and phonemes would have to counted manually from the thousands of texts. In addition, editors of the texts in PN have differing principles for what they consider nonstandard features. A new phoneme-based search engine is under development, however which will increase the searchable number of nonstandard attestations.
} 
match the four of Greek (/i, y, e, e/) (Gignac 1991, 187). With frequent fluctuation between $<\bar{e}, \mathrm{e}, \mathrm{i}>\mathrm{it}$ becomes evident that the qualities of $/ \mathrm{e} /$ and /i/varied significantly in many Greek texts written by Egyptians. One possible reason for this could be that, typically for Afroasiatic languages, vowel quality came to be conditioned by the articulatory characteristics of the adjacent consonant in Coptic phonology.

The coarticulatory effect of consonants on vowels - i.e. the adaptation of the vowel quality to that of the adjacent consonant, in manner or place ${ }^{7}$ - was a major factor behind the nonstandard spellings in Greek loanwords in Coptic (Girgis 1966, 73), and seems to be the same in the Greek written by L1 Egyptian speakers: vowel quality appears to have followed that of the preceding or following consonant, whichever took preference (this matter is also studied on a small sample in Dahlgren 2016 and more in-depth in Dahlgren in prep.). In Coptic, for example / $\mathrm{i}$ / is often either fronted or retracted in connection to the articulatory place of the consonant, and represented accordingly by $<\mathrm{i}>[\mathrm{i}],<\overline{\mathrm{e}}>[\mathrm{e}]$ or $<\mathrm{e}>[\mathrm{e}]$, even $<\mathrm{a}>[\mathrm{a}]$ (see Lambdin 1958 already on this). Likewise, it seems that the Egyptian L2 Greek speakers produced more front/close vowels adjacent to front consonants and more retracted/open ones when vowel quality was affected by back consonants nearby.

In Coptic, there was a distinction of quality between eta and epsilon, $<\overline{\mathrm{e}}>$ representing /e/ and $<\mathrm{e}>/ \varepsilon /$, which might have caused even more confusion because there were close-mid and open-mid front vowels in Coptic to match the closely articulated close-mid and raised close-mid front vowels /e/ and /e/ in Greek. In Greek, these front vowels developed in different directions with $<\mathrm{e}>$ remaining $[\mathrm{e}]$ and $<\overline{\mathrm{e}}>$ being ultimately raised to [i] (for Coptic vowel qualities, see Peust 1999, 201; for Greek vowels, see Horrocks 2010, 165-168). Two words from the O.Narm. corpus demonstrate the highly fluctuant nature of the /i, e/ variation even within a small corpus of 133 texts written by only a handful of scribes (4-6). This is the most frequent nonstandard phenomenon to occur in any Greek texts, so evidence from everywhere in Egypt is plentiful.

7 Coarticulation in this paper is to be understood as defined by Kühnert \& Nolan $(1999,7)$ : "Coarticulation, very broadly, refers to the fact that a phonological segment is not realized identically in all environments, but often apparently varies to become more like an adjacent or nearby segment." An excellent study to understanding how some languages seem to code more information on the consonantal quality than on that of the vowel is Traunmüller (1999). 
(4) Spelling variants of /i, e/

Standard

(a) <mētropolei $>$ mētropólei

(b) < k $\mathrm{k}^{\mathrm{s}}$ ylopōlēs $>k^{\mathrm{s}}$ ylopólēs
Nonstandard

<metropoli> metropoli O.Narm. 110.3

$<\mathrm{k}^{\mathrm{s}}$ ylōpōlis $>k^{\text {s}}$ ylopolis O.Narm. 21.1

In (4a), the standard mètropólei 'town (dat.)' has been written nonstandardly $<$ metropoli $>$, the original word-final dative marker - $e i$ [i] having been replaced with the contemporary phonetic variant of the diphthong, $<\mathrm{i}>$ [i]. Furthermore, the first syllable contains $<\mathrm{e}>(/ \mathrm{e} / \mathrm{in}$ Greek) instead of $<\overline{\mathrm{e}}>$ (/e / in Greek). (4b) has $<\mathrm{k}^{\mathrm{s}}$ ylōpōlis $>$ instead of $K^{s}$ ylopoles (personal name); this time $<\mathrm{i}>$ replaces the standard $<\overline{\mathrm{e}}>$ in the last syllable - both $<$ ei $>$ and $<\overline{\mathrm{e}}>$ had a very narrow articulation at this time and were on their way to [i] (Horrocks 2010, 167-168). A consonant-to-vowel coarticulatory effect could seriously be considered to be the cause behind these writing forms, even though much of the variation between /i, e/ may be random in later periods, with increased progress in Greek vowel raising. In the texts of $0 . N a r m$. there is still variation between $<\mathrm{e}>/ \mathrm{e} /$ and $<\overline{\mathrm{e}}>/ \mathrm{e} /$ as well as $<\overline{\mathrm{e}}>/ \mathrm{e} /$ and $<\mathrm{ei}>/ \mathrm{ei}$, so clearly neither $<\overline{\mathrm{e}}>/ \mathrm{e} /$ nor $<\mathrm{ei}>/ \mathrm{ei} / \mathrm{had}$ fully merged with /i/ (the end result in Modern Greek). Therefore /i/ seems to have raised in quality due to the adjacent coronals in $<$ metropoli $>$ and $\left\langle\mathrm{k}^{\mathrm{s}}\right.$ ylōpōlis $>$. Likewise, in $<$ metropoli $>$ the close-mid $<$ e $>/$ e/ replaces the raised close-mid $<\overline{\mathrm{e}}>/ \mathrm{e} /$, probably due to the lowering effect of the preceding bilabial on the close vowel (see e.g. Flemming 2003 \& 2009). Most of the instances of /ei/ and /e/ being raised to [i] in the O.Narm. corpus involve adjacency to coronals, but the matter needs more investigation - especially as regards the potential anticipatory or carryover coarticulatory patterns evidenced on the vowels. A comparison extending to all Greek texts in Egypt will be carried out in Dahlgren (in prep.). The interchangeability of the close front vowels was so frequent that even approximate numbers are impossible to give, but preliminarily it is safe to say that they lie in tens of thousands of attestations within the Greek texts in Egypt, ranging from the 1st century BCE to $7^{\text {th }}$ century CE. ${ }^{8}$ How much of this relates to the nonstandard vowel quality following that of the adjacent consonant remains to be seen in future research on Egyptian Greek. Again, however, the scarcity of post-Classical Greek texts outside of Egypt remains a problem, since comparisons are not readily available during the period when vowel raising was still unfinished. The spelling

8 In Trismegistos Text Irregularities Database, e.g. $<$ ei $>$ being replaced with $<\mathrm{i}>$ gains 17322 attestations and the replacement of $<\overline{\mathrm{e}}>$ with $<\mathrm{e}>$ appears in 833 instances. 
mistakes in the inscriptions from Classical-period Attic - the predecessor for Koine (the form of Greek used in Roman-period Egypt) - have no connection to the consonantal environment (see Threatte 1980 for examples).

\section{Word-final unstressed vowels}

Egyptian was a stress-timed language with a tendency to reduce unstressed vowels. Syllable reduction, most often done by reducing the vowel quality, is a typical feature of stress-timed languages, caused by the need to maintain a steady rhythmic interval between syllables (see a good description of the differences in stress systems in e.g. Auer 2001, 1391-1393). In Coptic phonology, the vowel inventory for unstressed syllables was restricted. Most importantly, there was no unstressed /o/ (Peust 1999, 250-254, Girgis 1966, 81). The stress system of Egyptian is the least well-known area of the phonology of the language. There is some consensus, however, that stress was usually placed in ultima or penultima (Peust 1999, 273). According to my preliminary results, in trisyllabic or longer words stress seems to have mostly fallen on the penultima, while in disyllables stress seems to alternate, for reasons yet unknown. Nevertheless, word-finally the unstressed vowel seems to have been reduced to schwa, which in Coptic was mostly represented by $<\mathrm{e}>$ (more in Dahlgren in prep.). It appears that this phonological feature can also be found in Greek texts, with word-final Greek /o/ written with $\langle\mathrm{e}\rangle$, and sometimes vice versa, probably because for the Egyptian writer, these represented the same sound in an unstressed position.

Classical Greek was mora-timed and word-final vowels bore morphological distinctions. Roman-period Greek, however, had already changed into a stress-timed language, which made word-final vowel qualities perceptually weaker. In Egypt, the effect was further amplified by the tendency for unstressed vowels to undergo reduction, sometimes resulting in the confusion of different tenses and moods due to Egyptian transfer, seeing as how the grammatical information of these lay in the last syllable in Greek (Dahlgren \& Leiwo in prep.). Therefore, the nonstandard production of Greek was both phonetically and phonologically grounded. Phonological in that it was caused by the Greek internal phonological development, the impact of the Egyptian stress system and its transfer to Greek, and the use of Coptic unstressed allophones for the word-final vowels; phonetic in the graphemic-level 
representation of what looks like consonant-to-vowel coarticulation. ${ }^{9}$ The most interesting aspect of this Egyptian-influenced linguistic situation, however, is that word-final schwa is also found in letters written by non-Egyptian writers (Leiwo 2010, 114-118 \& forthc.), indicating that its use had spread to a wider population, perhaps giving rise to a uniquely Egyptian variety of Greek. Word-final /o/ has not been reduced to schwa in any of the dialects of Modern Greek (Trudgill $2003,53-54 ; 59)$, so this is unlikely to be a Greek-internal feature.

Examples of the graphemic realisation of the possible word-final schwa can be seen in (5) below. All but one have <e> representing Greek /o/. It is also noteworthy that while (a) kérason 'to mix (imp.)', (b) pémp ${ }^{s}$ on 'to send (imp.)' and (c) méllomen 'we are about to' are verbs, (d) képon 'garden' is a noun so the phenomenon is not restricted to only one lexical category. ${ }^{10}$ The sound intended, due to phonological transfer from Egyptian, was probably phonetically [ə]. Loss of wordfinal $-n$ was very frequent in the Greek of Egypt (Gignac 1976, 111), leaving the word-final vowel even more vulnerable to neutralisation. <mellomon> in P.Fay. (a private letter written by a Roman army veteran), however, has $<0>$ in the last syllable, replacing the /e/ of the standard form. This is probably a hypercorrection, which suggests the same phonetic form behind the grapheme as in all the other nonstandard forms, namely word-final schwa.

According to Leiwo (forthc.), the writer of this letter was not Egyptian. The writer of O.Claud., however, was Egyptian, but his writing habits were to a great extent connected to the Roman military garrison surroundings and possibly even learnt from them, although the writer himself was a civilian (Leiwo 2005, 239-243, 248-251; 2010, 101-106, 114-115). It therefore seems plausible that there existed an Egyptian variety of Greek, quite heavily affected by the structure of Egyptian, and possibly further spread as $\mathrm{TL}_{2}$ (a second language learners' (imperfect) version of the target language, sometimes fixed as the group's final version of it, as defined by Thomason 2001, 74-75) among other second language users of Greek residing in Egypt.

\footnotetext{
${ }^{9}$ For a similar comparison, see Dohlus 2005 for phonological grounding in German loanword usage in Japanese, and phonetic grounding in French loanwords.

10 Trismegistos gives 347 instances of $<$ e $>$ for $<0>$ and 242 of $<$ e $>$ for $<0>$.
} 
(5) Word-final schwa

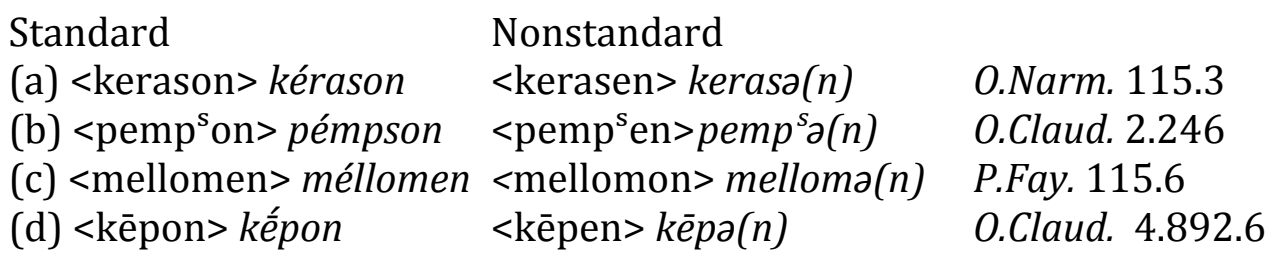

\section{Possible transfer of Egyptian stress onto Greek}

Nonstandard vowel usage mostly occurs in Greek unstressed syllables (see (5) above), but occasionally also in stressed ones. Applying Egyptian stress patterns, however, these nonstandard vowels, which in Greek are stressed, could often be analysed as unstressed. Following this hypothesis, word-internal unstressed /o/ could have been replaced by its Egyptian unstressed allophone /u/, as attested in Coptic. Transfer of Egyptian stress seems plausible in these cases. See for instance (6a) $<$ stryp $^{\mathrm{h}} \overline{\mathrm{e}} \mathrm{s}>$ from the standard strop ${ }^{h} \overline{\text { és }}$ 'turning (gen.)', in which the standard /o/ in the unstressed syllable has been replaced with $<y>$ [y], which was, due to the underdifferentiation of $/ y, u /$, a phonetic variant for $/ \mathrm{u} /$. On the other hand, in (6b) <lougou $>$ /lugu/ from the standard $<\operatorname{logou}>$ lógu 'word (sg.gen.)', the writer seems to have considered the first syllable unstressed regardless of the Greek original stress and again replaced what he possibly saw as unstressed /o/ with /u/. Here, the nonstandard orthographic form seems to indicate the transfer of the Egyptian stress system onto Greek, since in Coptic, stress in disyllabic words could fall on either syllable.

In (6c) <komiontai> komiontai from the standard <komiountai> komiúntai 'take care of', the same cause has the opposite result: the Greek stressed syllable with / $\mathrm{u} /$ seems to have been marked as stressed using Coptic orthographic practices for this, namely with <0> [o], apparently the most distinct vowel quality for a stressed syllable in Coptic. In this case, there is no transfer of stress. The preference in Coptic polysyllables was for the stress to fall on the penultima, thus coinciding with the position of stress in this Greek word. In fact, this was probably often the case. It is likely that Greek vowel quality was often retained when it matched the prosodic rules of Egyptian, masking on the written level most of the variation there may have been in speech. 
(6) Stress-related allophonic distribution of /o, u/

\begin{tabular}{lllll} 
Standard & \multicolumn{5}{c}{$\begin{array}{l}\text { Nonstandard } \\
\text { (a) }<\text { stroph }^{\mathrm{e}} \mathrm{s}>\end{array}$} & strop $^{h} \bar{e} S$ & $<$ stryp $^{\mathrm{h}} \overline{\mathrm{e}}>$ & stryp $^{h} e s$ & O.Narm. 92.6 \\
(b) $<$ logou $>$ & lógu & $<$ lougou $>$ & lugu & PSI 8.884.2
\end{tabular}

Note reverse order:

Standard Nonstandard

(c) <komiountai> komiúntai <komiontai> komiontai BGU 4.1123.6

\section{Greek loanwords in Coptic}

Greek loanwords in Coptic texts display phonological variation strikingly similar to Greek texts in Egypt: underdifferentiation of phonemes, stress-related allophonic variation, and transfer of the L1 stress system. They provide an apt point of comparison for verifying Egyptian influence in Greek nonstandard spellings as the writers of these texts were definitely Egyptian, and loanwords in general tend to be phonologically integrated into the native language (see e.g. Major 2001). (7) <stoullous> stullus from the standard <stylos> stýlos 'pillar' is an example of underdifferentiation of $/ y, u /$ in the first syllable, exactly as in (3) puru, except that this time the phenomenon occurs in a Greek stressed syllable. Judging by the vowel replacement in the second syllable, the standard /o/ having been replaced with / $\mathrm{u} /$, this is an instance where Coptic and Greek stress coincided, as it is quite probable that the reason for this change lies in the fact that, from the point of view of Coptic phonology, /o/ was disallowed in the unstressed syllable.

(8) < tremise > from the standard trimếsion 'tremis (a coin)' shows /i, e/ variation within a single word. The first syllable's /i/ has been replaced with /e/, and the second syllable's /e/ with /i/; the third syllable's /i/ in the Greek original is again replaced with /e/ in the nonstandard writing form. This is probably connected to the effect of stress as well as the coarticulatory effect of the consonants on vowels. The stress falls on the second syllable in the Greek original, and is acceptable there in Coptic as well (word-final -ion was according to Girgis (1966, 83-84) frequently lost in Greek loanwords in Coptic because of the weakened pronunciation of the Greek unstressed /o/ due to the impact of Coptic). It seems that the retraction of the standard /i/ to /e/ in the first syllable denotes an unstressed syllable with a weakened vowel quality. The second syllable has $\langle\overline{\mathrm{e}}\rangle$ in the standard form, and $<\bar{e}>$ had already been raised to $/ \mathrm{i} /$ in the $7^{\text {th }}-8^{\text {th }}$ century, to which the text corpus O.Frange 8 has been dated (Boud'hors 2010, 10). Therefore, $<\mathrm{i}>$ in the second syllable of the nonstandard form is most 
probably merely a phonetic spelling, and not indicative of a weakened vowel quality in an unstressed syllable. Regarding the coarticulatory effect of the consonants on the vowels, $\langle\overline{\mathrm{e}}\rangle$ in the standard occurs immediately before a coronal consonant /s/, which is an enhancing factor for the raising of vowel quality in that position. The first syllable /i/, on the other hand, precedes $/ \mathrm{m} /$, which is likely to cause lowering of the close vowel, as explained in Section 2 above. The nonstandard /e/ in the final syllable is probably a word-final schwa resulting from the substantially weakened quality of the unstressed /i/ in the standard form, especially since the final syllable has been omitted.

Word-final schwa is also encountered in (9) <noumes> numes from the standard <noummos $>$ númmos 'nummus'. Word-final $-s$ was deleted frequently in the same manner as word-final $-n$ so phonetically, the word probably ended in the final vowel. This time, vowel reduction from the unstressed /o/ resulted in schwa, and was represented by the grapheme <e>, similarly to the Greek words in (5) (retaining the original stress of the Greek word).

Example (10) could be a case of transfer of Coptic stress with the standard mok ${ }^{h}$ lós 'lever' being written $<$ mok $^{\mathrm{h} l o u s}>$. On the one hand, in the Greek (standard) word, the /o/ in the final syllable is stressed and should therefore cause no problems for an Egyptian speaker, but it has nevertheless been replaced here with $/ \mathrm{u} /$. On the other hand, although the /o/ in the first syllable is unstressed in Greek, it has not been replaced with a schwa. I therefore suggest that the Egyptian writer treated the Greek word according to the rules of his native language and again replaced what he understood as an unstressed /o/ with /u/, as would have been done in Coptic. It is so far not clear what the rules for stress placement in disyllabic words were, but in native Coptic they alternated. Peust $(1999,270-273)$ suggests that phrasal stress could have a role to play in such cases, but the subject requires a more thorough examination than is possible in this paper. Nevertheless, the perception of the $/ \mathrm{o} /$ in the second syllable as unstressed would require a change in the stress pattern, which seems to be what has happened here. For some reason not yet known, stress on the initial syllable in this example has seemed more suitable in terms of the Egyptian system. The transfer of Egyptian stress rules and the consequent allophonic patterns related to e.g. the /o, u/ distribution occurring in Greek words will continue to be analysed in more detail in Dahlgren (in prep.) and will hopefully be able to contribute to a more detailed understanding of Egyptian stress. 
(7) Underdifferentiation of Greek /y/ with /u/

$\begin{array}{llll}\begin{array}{l}\text { Standard } \\ \text { <stylos> stýlos }\end{array} & \begin{array}{l}\text { Nonstandard } \\ \text { <stoullous }>\end{array} & \text { stullus } & \text { P.Hamb.bil.1 }\end{array}$

(8) Consonant to vowel coarticulation: /i, e/

\begin{tabular}{|c|c|c|}
\hline $\begin{array}{l}\text { Standard } \\
<\text { trimēsion> }\end{array}$ & ion & $\begin{array}{l}\text { Nonstandard } \\
<\text { tremise }>\end{array}$ \\
\hline
\end{tabular}

(9) Word-final schwa

\begin{tabular}{|c|c|c|c|c|}
\hline $\begin{array}{l}\text { Standard } \\
<\text { noummos }>\end{array}$ & númmos & $\begin{array}{l}\text { Nonstandard } \\
<\text { noumes> }\end{array}$ & пита(s) & O.Frange 8 \\
\hline \multicolumn{5}{|c|}{ (10) Transfer of Coptic stress onto Greek } \\
\hline $\begin{array}{l}\text { Standard } \\
<\operatorname{mok}^{\mathrm{h}} l o s>\end{array}$ & mok ${ }^{h} l o ́ s$ & $\begin{array}{l}\text { Nonstandard } \\
<\mathrm{mok}^{\mathrm{h} l o u s>}\end{array}$ & mok $^{h} l u s$ & ab.bil.1 \\
\hline
\end{tabular}

\section{Arabic loanwords in Coptic: supporting evidence for Coptic phonology}

In order to distinguish between nonstandard features which belong to Greek internal development and which are part of the Egyptian system, it is possible to make a comparison between Greek loanwords and later Arabic loanwords in Coptic, as both display a number of nonstandard spellings revealing the spoken level of the language(s). Arabic loanwords in Coptic exhibit nonstandard variation similar to what can be seen in Greek loanwords in Coptic, deriving from the phonological structure of Egyptian. Renderings of Arabic loanwords are, again, partly phonetic: they reflect the Arabic phonetic reality in, for example, retaining $<\mathrm{a}>/ \mathrm{a} /$ in (11) after uvular consonants in the nonstandard <alkaroore> from al-qārūra 'flask' (example from Richter 2009, 425). Arabic has a phonological rule according to which $/ \mathrm{r} /$, uvulars and pharyngealised consonants retract vowel quality in coarticulation.11 Conversely, adjacency to coronals and other more front consonants tends to advance the vowel quality, and therefore $<a>$ is often replaced with <e> in Arabic loanwords in Coptic in these environments. However, Arabic loanwords also partly follow Egyptian phonological rules: the second syllable $/ \mathrm{u} /$ is stressed in Arabic, and probably therefore replaced with /o/ in Coptic, although the nearby / $\mathrm{r} /$ probably

\footnotetext{
11 See Blau (1979) for the phonological system of Arabic in the time period of Richter's examples of Arabic loanwords in Coptic (ninth to eleventh century CE, Middle Arabic).
} 
added to the retraction of the vowel quality. The word-final unstressed /a/ is again marked as schwa in Coptic, with <e $>$.

In (12), the writer has written <alkatah> for the standard al-qadah 'cup' (Richter 2009, 425). In this word, /d/ is replaced with /t/ as it is in the Greek word <atelfō> from adelfo in (2), which is proof of underdifferentiation of voiced/voiceless stops in Egyptian, thereby ruling out the possibility that such variation reflects some Greek internal developments instead of Egyptian influence. More examples and a more extensive analysis of using the Arabic loanwords in Coptic as evidence for Coptic phoneme qualities will again follow in Dahlgren (in prep.).

(11) Stress-related allophonic distribution of /o, u/

$\begin{array}{ll}\text { Standard (Arabic) } & \text { Nonstandard } \\ \text { al-qārúra } & \text { <alkaroore> }\end{array}$

(12) Underdifferentiation of voiced and voiceless stops

$\begin{array}{ll}\text { Standard (Arabic) } & \begin{array}{l}\text { Nonstandard } \\ \text { al-qadah }\end{array} \\ \text { <alkatah> }\end{array}$

\section{Discussion}

Since most of the writers of Greek texts displaying orthographic variation were native speakers of Coptic, it is hardly surprising that the nonstandard outcome of Greek written in Egypt contains features reflecting Egyptian phonology. However, perhaps the most prominent vowel feature of all has been evidenced also in texts written by nonEgyptian writers. This is the representation of a word-final unstressed vowel as schwa, a phenomenon linked to Egyptian prosodic rules. Variation is partly phonetically and partly phonologically grounded: it is affected by the Greek phonological development and the impact of Egyptian, including the suggested tendency to emphasise the coarticulatory effects of consonants on vowels. Further evidence for the Coptic phonological system can be gleaned from the spelling of Arabic loanwords in Coptic. These display the same phenomenon of stressinduced vowel reduction, as well as the effect of consonant-to-vowel coarticulation, providing information on Coptic phoneme qualities. On the phonological level, it seems that a genuine Egyptian Greek variety may have been in formation from the Roman period onward. This is likely to resemble the linguistic situation of, for example, Indian English, in which native language phonological transfer has had a similar effect on the linguistic outcome of the variety (cf. Deterding 2010: 392). In the Narmouthis ostraca, the contact effect is easily visible because of the imperfect knowledge of Greek of the writers, causing them to choose 
alternative spellings for the Greek words whose standard orthography they did not remember or know. After this preliminary sample, the matter will be investigated in more depth in Dahlgren (in prep.).

\section{Associated material}

The papyrological Navigator is an open-access network platform that hosts ca. 60,000 Greek texts and can be found at this web address: http://papyri.info. The searches for this article were performed in DDbDP. The Trismegistos platform can be found at this web address: http://www.trismegistos.org/textirregularities/texirr_type_list.php

\section{Comments invited}

PiHPh relies on post-publication review of the papers that it publishes. If you have any comments on this piece, please add them to its comments site. You are encouraged to consult this site after reading the paper, as there may be comments from other readers there, and replies from the author. This paper's site is here:

http://dx.doi.org/10.2218/pihph.1.2016.1695

\section{Acknowledgements}

I wish to thank Aleksi Mäkilähde for improving my English in this article. All remaining flaws are naturally my sole responsibility. I also wish to thank the comments from the editorial team and advisory board, especially those from Benjamin Molineaux. They made the argumentation of this paper significantly clearer.

\section{Author contact details}

\section{Sonja Dahlgren}

Department of World Cultures

Classical Philology, P.O. Box 24

00014 University of Helsinki

FINLAND

sonja.dahlgren@helsinki.fi 


\section{References}

Auer, Peter. 2001. Silben- und akzentzählende Sprachen. In Martin Haspelmath, Ekkehard König, Wulf Oesterreicher \& Wolfgang Raible (eds.), Language Typology and Language Universals. An International Handbook, 1391-1399. Berlin: De Gruyter.

Bagnall, Roger S. 2007. Reflections on the Greek of the Narmouthis Ostraca. In Mario Capasso \& Paola Davoli (eds.), New archaeological and papyrological researches on the Fayyum, Proceedings of the International Meeting of Egyptology and Papyrology, Lecce, June $8^{\text {th }}$ 10 th 2005, 14-21. Papyrologia Lupiensia 14.

Blau, Joshua. 1979. Some observations on a Middle Arabic Egyptian text in Coptic characters. Jerusalem Studies in Arabic and Islam 1. 215262.

Clarysse, Willy. 1993. Egyptian scribes writing Greek. In Chronique d'Egypte 68.135-136. 186-201.

Dahlgren, Sonja. 2016. Egyptian transfer elements in the Greek of Narmouthis ostraka. In Tomasz Derda, Adam Lajtar, Andrzej Mironczuk, Grzegorz Ochala \& Jakub Urbanik (eds.), The Proceedings of the 27th International Congress of Papyrology, Warsaw 29.07-3.08 2013: Volume II: Subliterary papyri, Documentary Papyri, Scribal Practices, Linguistic Matters. The Journal of Juristic Papyrology, 28: 1257-1263.

Dahlgren, Sonja (in preparation). Outcome of long-term language contact: transfer of Egyptian phonological features on Greek in Graeco-Roman Egypt. University of Helsinki, doctoral dissertation.

Dahlgren, Sonja \& Martti Leiwo (in preparation). Confusion of tense and modality? Impact of L1 phonological transfer on verb semantics.

Deterding, David. 2010. Variation across Englishes: Phonology. In Andy Kirkpatrick (ed.), The Routledge Handbook of World Englishes, 385399. Oxon: Routledge.

Dohlus, Katrin. 2005. Phonetics or phonology: Asymmetries in loanword adaptations-French and German mid front rounded vowels in Japanese. ZAS Papers in Linguistics 42. 117-135.

Flemming, Edward. 2009. The phonetics of schwa vowels. Phonological weakness in English. 78-98.

Flemming, Edward. 2003. The relationship between coronal place and vowel backness. Phonology 20. 335-373.

Gignac, Francis T. 1976. A grammar of the Greek papyri of the Roman and Byzantine periods. Volume I: Phonology. Milano: La Goliardica.

Gignac, Francis T. 1981. A grammar of the Greek papyri of the Roman and Byzantine periods. Volume II: Morphology. Milan: La Goliardica. 
Gignac, Francis T. 1991. Phonology of the Greek of Egypt, influence of Coptic on the. In Aziz S. Atiya (ed.). The Coptic Encyclopedia. Volume 8 of 8, 71-96. New York: Macmillan Publishers.

Girgis, W.A. 1966. Greek loan words in Coptic (Part II). In Bulletin de la Société d'Archéologie Copte 18. 71-96.

Horrocks, Geoffrey C. 2010 [1997]. Greek: A history of the language and its speakers. Oxford: Wiley-Blackwell.

Kühnert, Barbara \& Nolan, Francis. 1999. The origin of coarticulation. In William J. Hardcastle \& Nigel Hewlett (eds.), Coarticulation: Theory, Data and Techniques, 7-30). Cambridge: Cambridge University Press.

Lambdin, Thomas O. 1958. The bivalence of Coptic Eta and related problems in the vocalization of Egyptian. In Journal of Near Eastern Studies 17(3). 177-193.

Leiwo, Martti (forthcoming). Confusion of mood and tense in Greek private letters of Roman Egypt. In Mark Janse \& Klaas Bentein (eds.). Linguistic variation and change: Tense, aspect and modality in Ancient Greek. Amsterdam Studies in Classical Philology. Leiden: Brill.

Leiwo, Martti. 2010. Imperatives and other directives in the letters from Mons Claudianus. In Trevor V. Evans \& Dirk D. Obbink (eds.), The language of the papyri, 97-119. Oxford: Oxford University Press.

Leiwo, Martti. 2005. Substandard Greek. Remarks from Mons Claudianus. In Kennel, N.M. \& Tomlinson, Jonathan E. (eds.), Ancient Greece at the Turn of the Millennium. Recent Work and Future Perspectives. Proceedings of the Athens Symposium 18-20 May 2001, 237-261. Athens: Publications of the Canadian Archaeological Institute at Athens 4.

Loprieno, Antonio. 1995: Ancient Egyptian. A linguistic introduction. Cambridge: Cambridge University Press.

Major, Roy C. 2001. Foreign Accent: The ontogeny and phylogeny of second language phonology. Second Language Acquisition Research Series. Mahwah: Lawrence Erlbaum Associates.

Peust, Carsten. 1999. Egyptian phonology. An introduction to the phonology of a dead language. Göttingen: Peust und Gutschmidt.

Pintaudi, Rosario \& Pieter J. Sijpesteijn. 1993: Ostraka Greci da Narmuthis (OGN I). Quaderni di Medinet Madi 2. Pisa: Giardini Editori e Stampatori in Pisa.

Richter, Tonio Sebastian. 2009. Greek, Coptic and the 'language of the Hijra': the rise and decline of the Coptic language in late antique and medieval Egypt. In Hannah M. Cotton, Robert G. Hoyland, Jonathan J. Price, J. \& David J. Wasserstein (eds.), From Hellenism to Islam: 
Cultural and linguistic change in the Roman Near East, 401-446. Cambridge: Cambridge University Press.

Teodorsson, Sven.-Tage. 1977. The Phonology of Ptolemaic Koine. Göteborg: Acta Universitatis Gothoburgensis.

Thomason, Sarah G. 2001: Language contact. An introduction. Edinburgh: Edinburgh University Press.

Threatte, Leslie. 1980. The grammar of Attic inscriptions. Vol. 1, Phonology. Berlin: De Gruyter.

Traunmüller, Hartmut. 1999. Coarticulatory effects of consonants on vowels and their reflection in perception. In Proceedings from the XIIth Swedish Phonetics Conference, 141-144.

Trudgill, Peter. 2003. Modern Greek dialects: A preliminary classification. In Journal of Greek linguistics 4(1). 45-63.

Vierros, Marja. 2012. Bilingual notaries in Hellenistic Egypt. A study of Greek as a second language. Brussels: Collectanea Hellenistica 5. 